\title{
A comparative study of early leaf development in the Viola albida complex
}

\author{
Yong Kuk CHOI and Sung Soo WHANG* \\ Division of Science Education, Chonbuk National University, Jeonju 54896, Korea \\ (Received 13 February 2019; Revised 12 March 2019; Accepted 20 March 2019)
}

\begin{abstract}
Early leaves within the Viola albida complex were investigated by scanning electron microscopy in order to determine the morphological segments during morphogenesis. The early leaf development of $V$. albida var. albida could be morphologically divided into the eight stages in the following order: I, the initiation of shoot germination; II, the conical growth directionally of the leaf; III, the adaxial and abaxial formation of the leaf; IV, the initiation of the stipule; $\mathrm{V}$, the formation of a transitional zone between the leaf blade and petiole; VI, the expansion of the upper part of the leaf blade; VII, the formation of almost all parts of the early leaf; VIII, the early simple leaf. Viola albida var. takahashii differs from $V$. albida var. albida by additional stages, i.e., V-1, the initiation of the first lateral lobe at the both lateral parts of the leaf after the stage $\mathrm{V}$ and an early lobed leaf. Viola albida var. chaerophylloides is also distinguished from two taxa by two developmental features, V-2, the initiation of a second lateral lobe below of the first lateral lobe, and an early palmately compound leaf. These findings suggest that the Viola albida complex would be in the process of peramorphosis, showing developmental changes in a chain of events, leading to a different leaf shape. These data would also be useful for isolating genes that give rise to different leaf morphogenesis outcomes among the taxa in the Viola albida complex.
\end{abstract}

Keywords: Viola albida complex, early leaf development, peramorphosis

Taxonomic research required taxa, having morphological variations caused by frequent hybrid and/or vegetative reproduction in nature, have been called by several categories; microspecies (Davis and Heywood, 1963), superspecies (Mayr, 1969), semispecies (Grant, 1957; Baum, 1972), multispecies (Van Valen, 1976), species complex (Grant, 1981) etc. The Viola albida complex, consists of three taxa, $V$. albida var. albida, V. albida var. takahashii, and $V$. albida var. chaerophylloides, and these are sympatric (Kim et al., 1991). The frequent hybridization among taxa in this complex takes places, and there are almost absence of differences in taxonomic features for dividing species except for various leaves shape (Russell, 1960; Kim, 1986; Kim et al., 1991).

It has generally known that $V$. albida var. takahashii might be originated by the hybridization between $V$. albida var. albida and V. albida var. chaerophylloides (e.g., Kim, 1986). There is, however, no direct evidences regarding this so far. This complex shows numerous kinds of leaf forms in-between simple to palmately compound leaf, so that it is taxonomically difficult to explain (Kim and Lee, 1988; Kim et al., 1991; Jang et al., 2006; Whang, 2006). The results of morphological researches about this complex should give rise to debate in both the selection of scientific name (Regel, 1861; Maximowicz, 1877; Becker, 1902; Makino, 1912; Nakai, 1922a, 1922b; Ishidoya, 1929; Maekawa, 1954; Chung, 1959; Ito, 1962; Hashimoto, 1967; Lee, 1969, 1980; Park, 1974; Kim et al., 1991; Lee, 2003) and their classification system (Becker, 1925; Takenouchi, 1955; Maekawa and Hashimoto, 1963; Fu and Teng, 1977; Kim, 1986; Jang, 2012). Recent researches based on molecular data like DNA sequences, RAPD, ISSR, etc have supported the design adequacy of this complex (Yoo et al., 2004, 2005; Whang, 2006; Yoo and Kim, 2006; Koo et al., 2010). Further researches, however, are required to have better understand at the speciation and/or evolution in this complex. We have been conducting four different experiments on this complex; developmental investigation on early leaf morphogenesis (Choi, 2011), cross test between $V$. albida var. albida and $V$. albida var. chaerophylloides in both laboratory and wildness (An, 2015),

\footnotetext{
*Author for correspondence: whang@jbnu.ac.kr
} 
and both cloning and expression of several key genes responsible for leaf morphogenesis (Srikanth, 2014; Srikanth et al., 2019).

This study aims to determine morphological segments appearing in the early leaf development of Viola albida complex in order to give developmental clue for distinguishing taxa in the complex. The new data would be also useful as a basic reference for genes isolation responsible for different leaf morphogenesis if there are some successful results.

\section{Materials and Methods}

\section{Plant materials}

More than 1,000 individuals in Viola albida complex were collected from 2005 to 2015 at Naejangsan and Jeoksangsan Mountains for this study. They were transplanted at laboratory of about $66 \mathrm{~m}^{2}$ that has been regulated in both temperature and intensity of illumination, and their growth and development were observed more than seven years. The facilities locate in The 1st Science Building of Chonbuk National University. The individuals showing constant in shape during the several generations were selected for developmental studies.

\section{Seed germination and collection of young shoots}

The matured seeds were collected from both chasmogamous and cleistogamous flowers, and then stored at $4^{\circ} \mathrm{C}$ refrigerator. They were washed in tap water with liquid detergent for five minutes, and then sterilized using $70 \%$ ethanol and a mixture of distilled water $(250 \mu \mathrm{L})$, lax $(250 \mu \mathrm{L})$, and Triton X-100 $(25 \mu \mathrm{L})$. Sterilization was done by dipping the seeds in ethanol $70 \%$ for $1 \mathrm{~min}$ and transferring them to sodium hypochloride solution at $2 \%$ for $20 \mathrm{~min}$. Sterilized seeds were inoculated into $150 \mathrm{~mL}$ glass flasks containing $50 \mathrm{~mL}$ of MS medium (Murashige and Skoog, 1962) supplemented with $0.4 \mathrm{mg} / \mathrm{L}$ thiamine, $1 \mathrm{mg} / \mathrm{L}$ pyridoxine, $0.5 \mathrm{mg} / \mathrm{L}$ nicotinic acid, $100 \mathrm{mg} / \mathrm{L}$ mio-inositol and $0.5 \mathrm{~g} / \mathrm{L}$ hydrolyzed casein, diluted for the concentration defined in each treatment. The inoculation process was done under aseptic incubator in a sterile environment. The flask inoculated with sterilized seed were capped with plastic lids and transferred to a growth room. They were remained for six months at $23^{\circ} \mathrm{C}$ with $16 \mathrm{~h}$ lighting at an intensity of eight foot candles. Seeds were monitored daily and were evaluated for contamination and seed germination.

\section{Scanning electron microscopy}

Young shoots serially collected were fixed by $4 \%$ glutaraldehyde solution for the purpose of scanning electron microscopy (SEM) observation. After full fixation, young shoots were washed with distilled water and dehydrated with a graded ethanol series $(30,50,70,80,90,95$, and $100 \%)$ consisting of $10 \mathrm{~min}$ steps for each ethanol concentration followed by a graded ethanol-acetone series with three steps. Young shoots were subsequently freeze dried (VFD-21S, Hidachi, Tokyo, Japan), mounted on SEM stubs with doublesided adhesive tape, coated with gold in $15 \mathrm{~nm}$ thickness, and examined with a Hidachi ISI ABT (SR-50) SEM operated at $10 \mathrm{kV}$. All the stubs prepared are housed in the Botany Laboratory of Chonbuk National University.

\section{Results}

\section{General features in early leaf development}

The shape of shoot apical meristem (SAM) before germination is long elliptical in all taxa of Viola albida complex (Fig. 1A, B). The SAM, constituted with about 200 cells, of $V$. albida var. albida is a little bit smaller than those of $V$. albida var. takahashii and V. albida var. chaerophylloides, about 250 cells. After germination, the SAM showed gradual changes to develop young leaf. The morphogenesis of young leaves then were rapidly made up within a week, and their size reached up to around $1,000 \mu \mathrm{m}$ in width and $3,000 \mu \mathrm{m}$ in length (Figs. 1-3). The morphological segments of early leaf development, appeared in the taxa of the complex, could be distinguished in comparing the features of both mature leaves as well as general shapes in very early stages of germination. Morphological segments of early leaves development detected in this study were different among taxa in the complex (Figs. 1-3).

\section{Morphological segments of early leaves in Viola albida complex}

The features of early leaf development in $V$. albida var. albida was showed in Fig. 1 in detail. There are the SAM before germination (Fig. 1A), the initiation of germination (Fig. 1B), the initiation of conical growth directionally (Fig. 1C), ended up conical growth (Fig. 1D), the formation of adaxial and abaxial side of leaf (Fig. 1E), the initiation of stipule (Fig. $1 F)$, the formation of transitional zone between leaf and petiole (Fig. 1G), the expansion of upper part of leaf (Fig. 1H), the formation of almost all parts of early leaf (Fig. 1I), and the adaxial side of early simple leaf (Fig. 1J). The features of early leaf development in $V$. albida var. takahashii was showed in Fics 1-2 in detail. Its morphological segments during early leaf development are the same as those of $V$. albida var albida till the formation of transitional zone between leaf and petiole. The different features are, however, the first initiation of lateral lobe in both parts of leaf (Fig. 2A), the expansion of leaf blade (Fig. 2B), the formation of almost all of early leaf (Fig. 2C), 


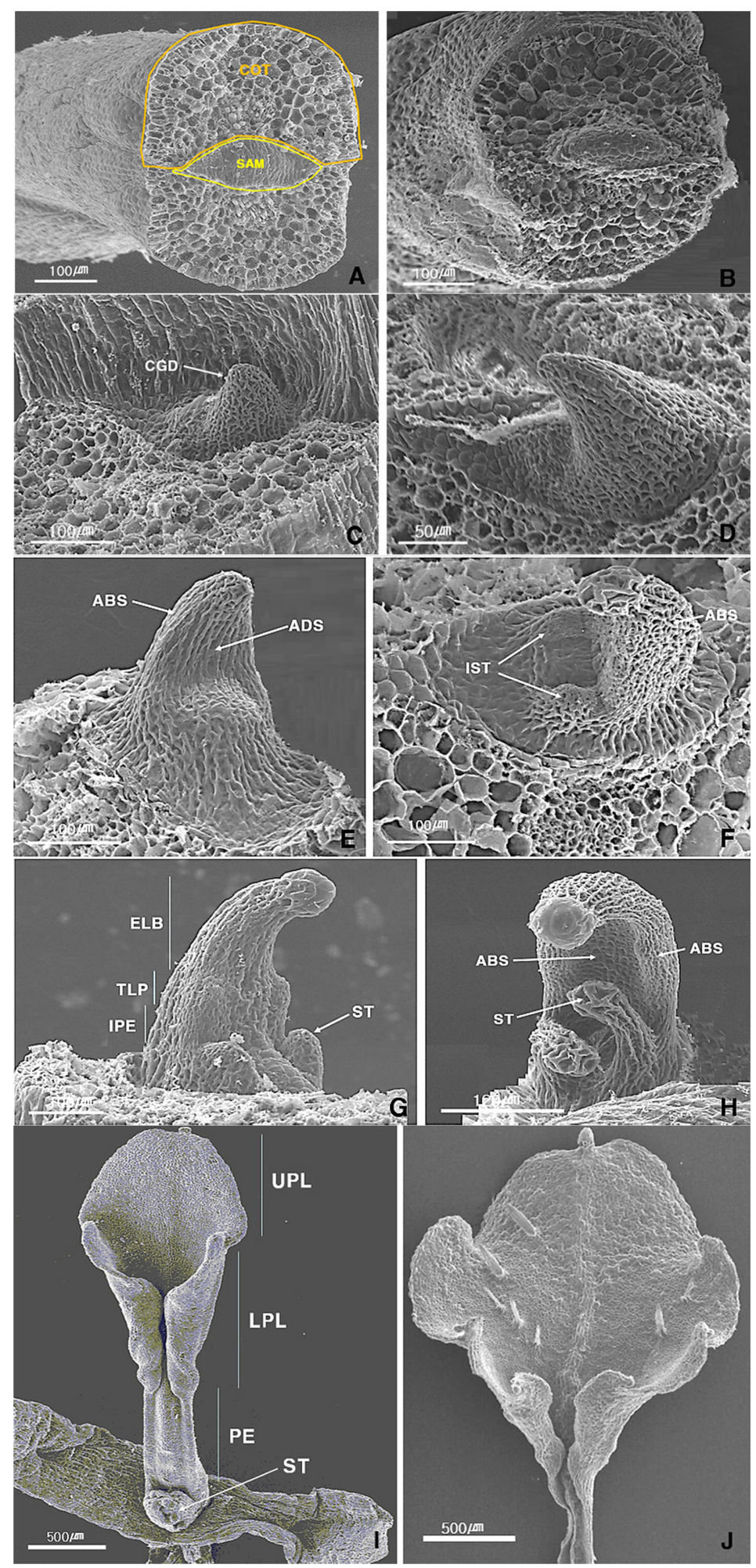

Fig. 1. Scanning electron micrographs of early leaf development in Viola albida var. albida. A. Shoot apical meristem before germination. B. Initiation of germination. C. Initiation of conical growth directionally. D. Ended up conical growth. E. Formation of adaxial and abaxial side of leaf. F. Initiation of stipule. G. Transitional zone between leaf and petiole. H. Expand of upper part of leaf. I. Formation of almost all parts of early leaf. J. Adaxial side of early simple leaf. ABS, abaxial side of leaf; ADS, adaxial side of leaf; CGD, conical growth directionally; COT, the site of tear off a cotyledon; ELB, early leaf blade; IPE, initiation of petiole; IST, initiation of stipule; LPL, lower part of leaf blade; PE, petiole; SAM, shoot apical meristem; ST, stipule; TLP, transitional zone between leaf and petiole; UPL, upper part of leaf blade. 

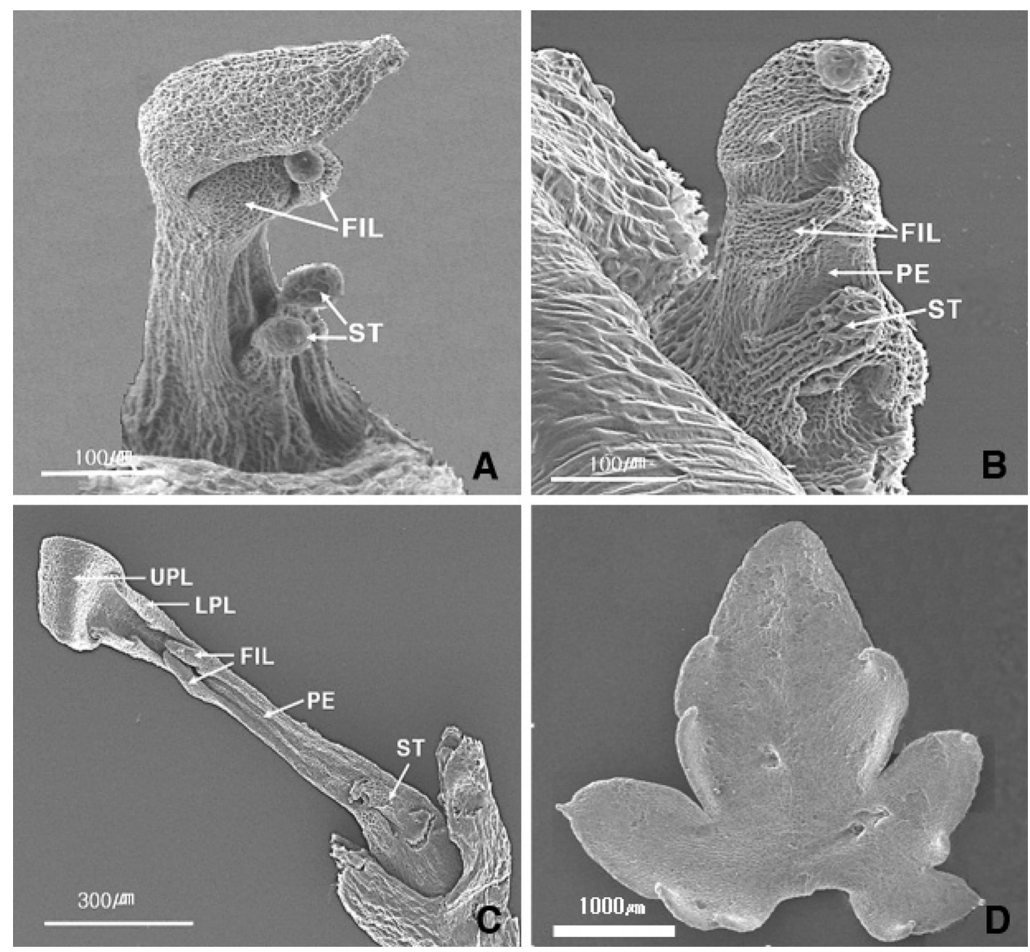

Fig. 2. Scanning electron micrographs of some early leaf development of Viola albida var. takahashii. A. First initial of lateral lobe at both parts of leaf. B. Expand of leaf blade. C. Formation of almost all of early leaf. D. Adaxial side of early lobed simple leaf. See Fig. 1. to know before Fig. 2A. FIL, first lobe of leaf; LPL, lower part of leaf; PE, petiole; ST, stipule; UPL, upper part of leaf.
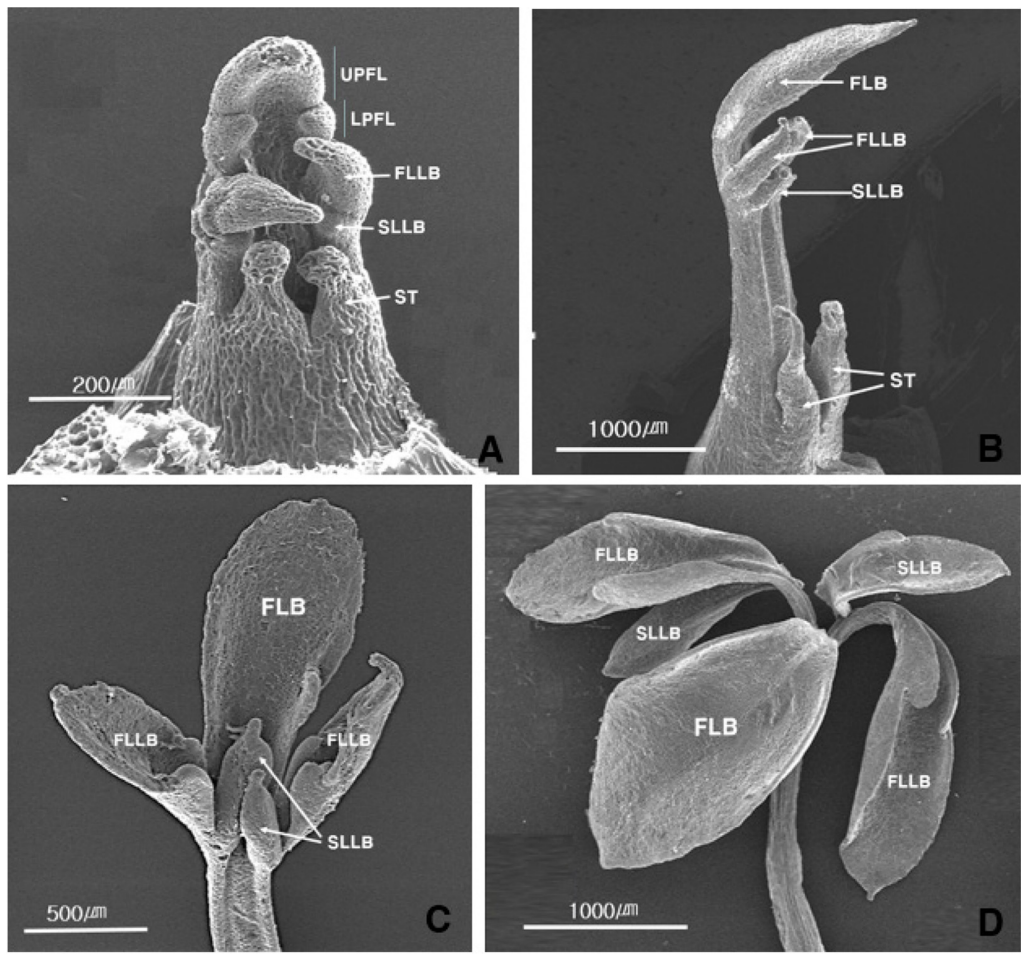

Fig. 3. Scanning electron micrographs of some early leaf development of Viola albida var. chaerophylloides. A. First initial of second lateral lobe at both parts of leaf. B. Formation of almost all of early leaf. C. Expand of leaf blade. D. Early palmate compound leaf. See Fig. 1. to know before Fig. 3A. FLB, first leaf blade; FLLB, first lateral leaf blade; LPFL, lower part of first leaf; SLLB, second lateral leaf blade; ST, stipule; UPFL, upper part of first leaf. 
and the adaxial side of early lobed simple leaf (Fig. 2D). The early leaf development of $V$. albida var. chaerophylloides was showed in Fics 1-3 in detail. Its morphological segments during early leaf development are the same as those of both $V$. albida var. albida till the formation of transitional zone between leaf and petiole and $V$. albida var. takahashii till the first initiation of lateral lobe of the leaf. The different features are, however, the first initiation of second lateral lobe in both parts of leaf (Fig. 3A), the formation of almost all of early leaf (Fig. 3B), the expansion of leaf blade (Fig. 3C), and the early palmately compound leaf (Fig. 3C).

In conclusion, taxa within the complex could be distinguished based on the features described above. The morphological segments of early leaf development in V. albida var. albida were categorized into eight stages: I, the initiation of shoot germination; II, the conical growth directionally of leaf; III, the adaxial and abaxial formation of leaf; IV, the initiation of stipule; $\mathrm{V}$, the formation of transitional zone between leaf blade and petiole; VI, the expansion of upper part of leaf blade; VII, the formation of almost all part of early leaf; VIII, the early palmate compound leaf. Viola albida var. takahashii is clearly separated from V. albida var. albida by the features of both V1 , the initiation of first lateral lobe at both parts of early leaf, and VIII, the early lobed simple leaf. Viola albida var. chaerophylloides is also separated from $V$. albida var. albida and $V$. albida var. takahashii by three features, V-1, the initiation of first lateral lobe at both parts of early leaf, V-2, the second lateral lobe at the below of first lateral lobe, and VIII, the early palmate compound leaf.

\section{Discussion}

Viola albida var. albida distributes widely on the Korean Peninsula, and its speciation course is of interest. This species complex consists of three taxa, $V$. albida var. albida, $V$. albida var. takahashiii, and $V$. albida var. chaerophylloides (Kim et al., 1991). Interestingly, it is not difficult to find the spots where all taxa in this complex are sympatric distribution or neighborhood areas across many of mountains (Whang, 2006). Taxa in this complex hardly find differences in taxonomic characters except for various leaves shapes. There are, however, numerous leaf shapes from simple to palmately compound forms together with intermediate types in-between, so that the establishment of both species limitation and classification have long been debating among researchers (e.g., Kim et al., 1991; Whang, 2006; Jang, 2012). Many researches on this complex have been conducted because of this exciting attention to taxonomists (e.g., Kim et al., 1991; Jang, 2012). The authors have been also studying for

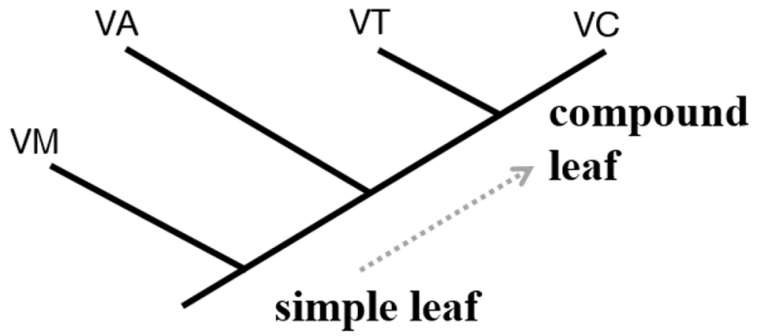

Fig. 4. A suggested dendrogram of the Viola albida complex based on Table 1 data. VA, V. albida var. albida; VC, V. albida var. chaerophylloides; VM, V. mandshuria; VT, V. albida var. takahashii.

several decades to this complex in order to find the courses of speciation and evolution (Whang and Kim, 1985; Kim et al., 1991; Whang, 2006; Koo et al., 2010).

It is too difficult to prove the evolution of organism that is a phenomenon gradually taking place for a long time (e.g., Barrick et al., 2009). It is also never easy for what the experimental demonstration as to morphological changes taking place in real time on the basis of the evolutionary point of view. In these context, we have recently done four different experiments for this complex: 1) the investigation of morphogenesis from seed germination to early leaf shape (Choi, 2011), 2) the investigation of the leaf features of second generation after the cross test in both laboratory and wildness (An, 2015), 3) cloning of genes that have directly related to the morphological segments during early leaf development (Srikanth, 2014), and 4) and the investigation of the expression pattern of their genes (Srikanth, 2014; Srikanth et al., 2019).

This article is about a comparative study of early leaf development showing the morphological segments. This data, showing developmental differences, were primary useful as some diagnostic features to distinguish the taxa in the complex. This data would be employed not only for cloning of genes that have directly related to the morphological segment during early leaf development, but also for testing their differential expression pattern (Srikanth et al., 2019).

The data obtained this study were Figs. 1-3, and their scientific interpretations summed up in Fig. 4 and Table 1. On the basis of Table 1, the crucial morphological differences among taxa could be summarized as follows. After the development of feature $\mathrm{V}$ (the formation of transitional zone between leaf blade and petiole) in $V$. albida var. albida, two features, V-1 (the initial of first lateral lobe at both parts of early leaf) and V-2 (the initial of second lateral lobe at the below of first lateral lobe), were repeatedly developed in $V$. albida var. takahashii and $V$. albida var. chaerophylloides 
Table 1. Some diagnostic characters from early leaf development of the Viola albida complex.

\begin{tabular}{|c|c|c|c|c|c|}
\hline \multirow{2}{*}{ Characters } & \multirow{2}{*}{ Character numbering } & \multicolumn{4}{|c|}{ Taxa } \\
\hline & & VA & VT & $\mathrm{VC}$ & $\mathrm{VM}^{\mathrm{a}}$ \\
\hline Initiation of shoot germination & I & $\mathrm{O}$ & $\mathrm{O}$ & $\mathrm{O}$ & $\mathrm{O}$ \\
\hline Conical growth directionally of leaf & II & $\mathrm{O}$ & $\mathrm{O}$ & $\mathrm{O}$ & $\mathrm{O}$ \\
\hline Adaxial and abaxial formation of leaf & III & $\mathrm{O}$ & $\mathrm{O}$ & $\mathrm{O}$ & $\mathrm{O}$ \\
\hline Initiation of stipule & IV & $\mathrm{O}$ & $\mathrm{O}$ & $\mathrm{O}$ & $\mathrm{O}$ \\
\hline Formation of transitional zone between leaf blade and petiole & $\mathrm{V}$ & $\mathrm{O}$ & $\mathrm{O}$ & $\mathrm{O}$ & $\mathrm{O}$ \\
\hline Initial of first lateral lobe at both parts of early leaf & $\mathrm{V}-1$ & N/A & $\mathrm{O}$ & $\mathrm{O}$ & N/A \\
\hline Initial of second lateral lobe at the below of first lateral lobe & $\mathrm{V}-2$ & $\mathrm{~N} / \mathrm{A}$ & N/A & $\mathrm{O}$ & N/A \\
\hline Expand of upper part of leaf blade & VI & $\mathrm{O}$ & $\mathrm{O}$ & $\mathrm{O}$ & $\mathrm{O}$ \\
\hline Formation of almost all part of early leaf & VII & $\mathrm{O}$ & $\mathrm{O}$ & $\mathrm{O}$ & $\mathrm{O}$ \\
\hline Early simple heart leaf & VIII & $\mathrm{O}$ & $\mathrm{O}$ & $\mathrm{O}$ & N/A \\
\hline Early lobed simple leaf & VIII-1 & N/A & $\mathrm{O}$ & $\mathrm{O}$ & N/A \\
\hline Early palmately compound leaf & VIII-2 & N/A & N/A & $\mathrm{O}$ & N/A \\
\hline
\end{tabular}

See Figs. 1-3 for the abbreviation of Arabian number.

VA, V. albida var. albida; VT, V. albida var. takahashii; VC, V. albida var. chaerophylloides; VM, V. mandshirica; N/A, not available. ${ }^{\mathrm{a} O u t}$ group.

respectively. There were, therefore, absent in two features like $\mathrm{V}-1$ and V-2 in $V$. albida var. albida, and also absent in the feature V-2 in V. albida var. takahashii, so that these two taxa were clearly distinct from $V$. albida var. chaerophylloides. In addition, two different types of heterochrony, like spatial and temporal changes in development in a descendant relative to its ancestor, has long been known as the mechanisms most important for evolution (Haeckel, 1875).

The meaning of above differences would be that two taxa, V. albida var. takahashii and V. albida var. chaerophylloides, are peramorphosis comparing to the ancestor, $V$. albida var. albida. Because these two taxa have evolved excessive stages besides all developmental stages of ancestor type (e.g., Buendía-Monreal and Gillmor, 2018). A suggested topology based on the above shows in Fig. 4. In putting $V$. mandshurica having simple leaf as an out-group, V. albida var. albida had initially originated in the Korean Peninsular and/or its neighborhood area, and then $V$. albida var. takahashii and $V$. albida var. chaerophylloides might have been originated caused by hybridization with other species and/or genetic changes.

ORCID: Sung Soo WHANG https://orcid.org/0000-00025544-0180

\section{Acknowledgments}

This study was partly supported by a research grant of
Chonbuk National University (2018-2019).

\section{Conflict of Interest}

The authors declare that there are no conflicts of interest.

\section{Literature Cited}

An, S. H. 2015. A speciation study of Viola albida complex based on artificial hybridization. Master thesis, Chonbuk National University, Jeonju, Korea, 24 pp.

Barrick, J. E., D. S. Yu, S. H. Yoon, H. Jeong, T. K. Oh, D. Schneider, R. E. Lenski and J. F. Kim. 2009. Genome evolution and adaptation in a long-term experiment with Escherichia coli. Nature 461: 1243-1247.

Baum, B. R. 1972. Avena septentrionalis, and the semispecies concept. Canadian Journal of Botany 50: 2063-2066.

Becker, W. 1902. Violaceae. Bulletin de l'Herbier Boissier, Serie II 2: 856 .

Becker, W. 1925. Viola. In Die Naturlichen Pflanzenfamilien. Vol. 21. Engler, A. and K. Prantl (eds.), Engelmann, Leipzig. Pp. 363-377.

Buendía-Monreal, M. and C. S. Gillmor. 2018. The times they are A-Changin': heterochrony in plant development and evolution. Frontiers in Plant Science 9: 1349.

Choi, Y. K. 2011. Study on the development of plant leaves in Viola albida complex using scanning electron microscopy. Master 
thesis, Chonbuk National University, Jeonju, Korea, 28 pp.

Chung, T. H. 1959. A key of the species of Violaceae from Korea. Korean Journal of Botany 2: 25-26.

Davis, P. H. and V. H. Heywood. 1963. Principles of Angiosperm Taxonomy. Van Nostrand, Princeton, NJ, 556 pp.

Fu, P. Y. and Y. C. Teng, 1977. Flora Plantrum Herbacearum Chinae Boreali-Orientalis. Tomus 6. Science Publication, Beijing. Pp. 79-129.

Grant, V. 1957. The plant species in theory and practice. In The Species Problem. Mayr, E. (ed.), American Association for the Advancement of Science, Washington, D.C. Pp. 39-80.

Grant, V. 1981. Plant Speciation. 2nd ed. Columbia University Press, New York, 432 pp.

Haeckel, E. 1875. Die Gastrula und die Eifurchung der Thiere. Jenaische Zeitschrift für Naturwissenschaft 9: 402-508.

Hashimoto, T. 1967. Violets of Japan. Sunmoondang, Tokyo. 280 pp. Ishidoya, T. 1929. Review of Viola from Korean and Manshuria. Journal of Chosen Natural History 8: 15-17.

Ito, E. 1962. Observations on the variations of the Chaerophylloides-Group of Viola in Japan. Bulletin of the National Science Museum of Japan 6: 192-203.

Jang, S.-K. 2012. Phylogenetic study of Viola section Pinnatae Wang. PhD dissertation, Kangwon National University, Chuncheon, Korea, 199 pp.

Jang, S.-K., W.-T. Lee and K.-O. Yoo. 2006. Taxonomic study on Viola albida var. albida and its related taxa. Korean Journal of Plant Taxonomy 36: 163-187.

Koo, J. C., H. J. Tak and S. S. Whang. 2010. Taxonomic study of Viola albida complex based on RAPD data. Korean Journal of Plant Taxonomy 40: 118-129.

Kim, K. S. 1986. Studies of comparative morphology on the Korean Viola species. PhD dissertation, Sungkyunkwan University, Suwon, Korea, 105 pp.

Kim. K. S. and C. D. Lee. 1988. The systematic value of leaf venation patterns of Viola species in Korea. Korean Journal of Plant Taxonomy 18: 173-189.

Kim, K. S, B. Y. Sun, S. S. Whang and G. H. Chung. 1991. Biosystematic study on the genus Viola in Korea: comparative morphology of the Viola albida complex. Korean Journal of Botany 34: 229-238. (in Korean)

Lee, T. B. 1969. Plant resources on Korea. Bulletin of Seoul National University (Biological Agriculture) 20: 158-159.

Lee, T. B. 1980. Illustrated Flora in Korea. Hyangmoonsa, Seoul, 990 pp.

Lee, T. B. 2003. Coloured Flora of Korea. Hyangmoonsa, Seoul, I, 914 pp, II, 910 pp. (in Korean)

Maximowicz, C. J. 1877. Diagnoses plantarum novarum asiaticarum. Bulletin de l'Academie Imperiale des Sciences de St.-
Petersbourg 23: 312-314.

Mayr, E. 1969. Principles of Systematic Zoology. McGraw-Hill, New York, 416 pp.

Maekawa, F. 1954. Violaceae. In Enumeratio Spermatophytraum Japonicum, III. Hara, H. (ed.), Iwanami, Tokyo. Pp. 194-227.

Maekawa, F. and T. Hashimoto. 1963. Violet of Japan: 2. Shibundo-shinko-sha, Tokyo. Pp. 1-9.

Makino, T. 1912. Observations on the flora of Japan. Botanical Magazine Tokyo 26: 208-211.

Murashige, T. and F. Skoog. 1962. A revised medium for rapid growth and bio assays with tobacco tissue cultures. Physiologia Plantarum 15: 473-497.

Nakai, T. 1922a. Notes on Viola. Botanical Magazine Tokyo 36: 52-61, 84-93, 118-121.

Nakai, T. 1922b. Violae Novae Jponicae. Botanical Magazine Tokyo 34: 29-39.

Park, M. K. 1974. Key to the Herbaceous Plants in Korea (Dicotyledoneae). Jeumumsa, Seoul. Pp. 272-274. (in Korean)

Regel, E. 1861. Violaceae. Pl. Radd. 1: 222.

Russell, N. H. 1960. Studies in the photoperiodic responses of violets (Viola). The Southwestern Naturalist 5: 177-186.

Srikanth, K. 2014. Differential expression of certain key genes mediate leaf morphology variation in Viola albida complex. $\mathrm{PhD}$ dissertation, Chonbuk National University, Jeonju, Korea, 153 pp.

Srikanth, K., R. S. Hill and S. S. Whang. 2019. A correlation between leaf shape and its related key genes in Viola albida complex. In Vitro Cellular \& Developmental Biology - Plant. In press.

Takenouchi, M. 1955. Brief notes on taxonomy, ecology and geographic distribution of species of Viola indigenous to Manchuria and Inner-Mongolia. Science Contribution of Tung-pei Teacher University 5: 65-95.

Van Valen, L. 1976. Ecological species, multispecies, and oak. Taxon 25: 233-239.

Whang, S. S. 2006. Analysis of ITS DNA sequences of the Viola albida complex. Korean Journal of Plant Resources 19: 628633.

Whang, S. S. and K. Kim. 1985. A preliminary study on the palynotaxonomy of Korean violets. Basic Science Review 8: 53-56.

Yoo, K.-O., S.-K. Jang and W.-T. Lee. 2005. Phylogeny of Korean Viola based on ITS sequences. Korean Journal of Plant Taxonomy 35: 7-23.

Yoo, K.-O and J.-H. Kim. 2006. Analysis of taxonomic relationships of Korean Viola based on trnL-trnF region sequences of chloroplast DNA. Flower Research Journal 14: 232-240.

Yoo, K.-O., W.-T. Lee and O.-K. Kwon. 2004. Interspecific relationships of Korea Viola based on RAPD, ISSR and PCRRFLP analyses. Korean Journal of Plant Taxonomy 34: 43-61. 